\title{
Editorial
}

\section{Issues in the African Banking Context}

Journal of Financial Services Marketing (2011) 16, 275-276. doi:10.1057/fsm.2011.29

The last three articles in this double issue cover a range of topics from the African banking context. The first of these is Delport, Steyn and Mostert's paper, 'Relationship intention of South African banking and life insurance customers', which focuses on the factors affecting relationship intention among customers of South African financial institutions. Banks and other financial institutions globally are facing similar challenges in terms of competition, resulting in a focus on retaining customers and building long-term relationships with them. However, not all customers are willing to develop long-term relationships. The task for banks is to identify and target those customers who intend to develop and maintain a long-term relationship with the firm, that is, those with a high relationship intention. The objective of the study was to investigate the constructs constituting relationship intention and to determine whether differences exist between high and low relationship intention customers for the relationship intention constructs.

On the basis of a non-probability, convenience sample of 401 respondents, the study identifies five constructs constituting relationship intention: involvement, expectations, forgiveness, feedback and fear of relationship loss. Moreover, the authors note that high and low relationship intention respondents perceive four of the five constructs differently. In comparison with low relationship intention respondents, high relationship intention respondents have a greater desire to be more involved with their banks or life insurance providers, have significantly greater expectations from their banks or life insurance providers, are more likely to forgive their banks or life insurance providers for service failures or increased rates, and place a significantly higher premium on giving feedback to, and receiving feedback from, their banks and life insurance providers. The authors suggest a differential marketing approach for low versus high relationship intention customers.

The second article, 'Effects of demographic factors on bank customers' attitudes and intention towards Internet banking (IB) adoption in a major developing African country', by Onyia and Tagg, provides an insight into the factors affecting Internet adoption in Nigeria. The authors note that in spite of having the fastest pace and largest scope of Internet penetration in Africa, Nigeria is still struggling to convince its huge population to adopt IB. The focus of the study is on demographic variables. Although many studies of IB have made use of personal demographic variables to categorize respondents, only a few of the existing studies in the area have focused on the actual influence of these factors on the adoption attitudes of the banking customers. There are potentially key social and economic factors related to developing countries that make the use of demographic factors more potent in behavioural prediction.

The study examines the influence of seven demographic variables - age, gender, level of 
education, marital status, employment status, income level and area of residence - on retail banking customers' behaviours towards IB adoption. A sample of 500 customers was surveyed by means of a multi-mode survey that included web-based, email and paper versions of the same questionnaire, out of which 317 responded. The study concludes that gender, level of education and employment status are the major demographic factors influencing Nigerian banking customers' attitudes to IB adoption. The article discusses implications of the findings and limitations of the study.

The final article, 'Market orientation as a competitive tool: empirical evidence from "quartile one" banks in Ghana', by Mahmoud, Kastner and Akyea, examines the incidence of market orientation among the top four (so-called 'quartile one') banks in Ghana. The positive impact of market orientation is generally understood, yet few studies have focused explicitly on its implications for banks, let alone banks in a developing country. The study adopts a case study approach focusing on the top four banks in Ghana. On the basis of in-depth face-to-face interviews with eight managers and questionnaires completed by 109 managers, the article provides an insight into the nature and scope of market orientation.

Qualitative data reveals that customer orientation seems to dominate the nature of bank market orientation, while the quantitative findings show strong emphasis on intelligence dissemination. Regression analysis reveals that top management emphasis, market-based reward systems and interdepartmental coordination are the essential internal values for developing market orientation in the case study banks. Market orientation seems to be a significant factor in achieving high levels of employees' esprit de corps and customer satisfaction which are particularly viable for banks facing severe competition, technological turbulence, and operating in a weak economy. The article discusses the implications of the findings and avenues for further research.

Tina Harrison Editor-in-Chief 